$\mathbf{R}_{\text {ESE }}^{\text {RCH }}$ RTICLe

Members of the Research Forum Associate Author :

${ }^{1}$ Department of Zoology, Justice Basheer Ahmed Sayeed College for Women (Autonomous), CHENNAI (T. N.) INDIA

Email : cmnoorjahan@gmail.com

AUTHOR FOR CORRESPONDENCE : SHEEBA ALI SIDDIQUI Department of Zoology, Justice Basheer Ahmed Sayeed College for Women (Autonomous), CHENNAI (T. N.) INDIA

Email : sheebaalisiddiqui90@ gmail.com

\section{Estimation of biochemical constituents in different vegetables}

Abstract : The right foundation to good health is to choose food product that are rich in nutrients and have a balanced amount of nutrient like carbohydrates, proteins, minerals, vitamins and little bit of fat as well. If you choose your food wisely, you will be able to enjoy the experience of eating, as the right foods will help you remain healthy. In this present study, the estimation of biochemical constituents such as carbohydrates, proteins and lipids present in following vegetables such as Solanum tuberosum L. (Potato), Raphanus sativus (Radish), Solanum lycopersicum L. (Tomato), Cucumis sativus (Cucumber) and Allium cepa (Onion) were carried out. The results of the amount of carbohydrates present in vegetables showed that Raphanus sativus (Radish) has the high content of carbohydrates followed by Solanum tuberosum L. (Potato), Cucumis sativus (Cucumber), Allium cepa (Onion) and Solanum lycopersicum L. (Tomato). The results of the amount of proteins present in vegetables showed that Allium cepa (Onion) has large amount of proteins followed by Solanum lycopersicum L. (Tomato), Raphanus sativus (Radish), Cucumis sativus (Cucumber) and Solanum tuberosum L. (Potato) and the results of the amount of lipids present in vegetables showed that Raphanus sativus (Radish) has the high content of lipids followed by Solanum lycopersicum L. (Tomato), Solanum tuberosum L. (Potato), Cucumis sativus (Cucumber) and Allium cepa (Onion).

Key words : Vegetables, Carbohydrates, Proteins, Lipids

How to cite this paper : Siddiqui, Sheeba Ali and Noorjahan, C.M. (2017). Estimation of biochemical constituents in different vegetables. Vet. Sci. Res. J., 8(1\&2) : 41-46, DOI : 10.15740/HAS/VSRJ/8.1 and2/41-46.

Paper History : Received : 27.04.2017; Revised : 07.09.2017; Accepted : 22.09.2017 